\title{
Assessing Surface Heat Flux Products with In Situ Observations over the Australian Sector of the Southern Ocean
}

\author{
Vidhi Bharti, ${ }^{\mathrm{a}, \mathrm{b}}$ ERIC SCHUlz, ${ }^{\mathrm{c}}$ CHRISTOPHER W. FAIRALl, ${ }^{\mathrm{d}}$ BYRON W. BlOMQUist, ${ }^{\mathrm{d}}$ \\ Yi Huang,,${ }^{\mathrm{e} f}$ Alain Protat, ${ }^{\mathrm{c}}$ Steven T. Siems,,${ }^{\mathrm{a}, \mathrm{b}}$ And Michael J. Manton ${ }^{\mathrm{a}}$ \\ ${ }^{a}$ School of Earth, Atmosphere and Environment, Monash University, Clayton, Victoria, Australia \\ ${ }^{\mathrm{b}}$ Australian Research Council Centre of Excellence for Climate System Science, Monash University, \\ Melbourne, Victoria, Australia \\ ${ }^{\mathrm{c}}$ Australian Bureau of Meteorology, Melbourne, Victoria, Australia \\ ${ }^{\mathrm{d}}$ National Oceanic and Atmospheric Administration/Earth Systems Research Laboratory, Boulder, Colorado \\ ${ }^{\mathrm{e}}$ School of Earth Sciences, University of Melbourne, Melbourne, Victoria, Australia \\ ${ }^{\mathrm{f}}$ Australian Research Council Centre of Excellence for Climate Extremes, University of Melbourne, \\ Melbourne, Victoria, Australia
}

(Manuscript received 30 January 2019, in final form 5 July 2019)

\begin{abstract}
Given the large uncertainties in surface heat fluxes over the Southern Ocean, an assessment of fluxes obtained by European Centre for Medium-Range Weather Forecasts interim reanalysis (ERA-Interim) product, the Australian Integrated Marine Observing System (IMOS) routine observations, and the Objectively Analyzed Air-Sea Heat Fluxes (OAFlux) project hybrid dataset is performed. The surface fluxes are calculated using the COARE 3.5 bulk algorithm with in situ data obtained from the NOAA Physical Sciences Division flux system during the Clouds, Aerosols, Precipitation, Radiation, and Atmospheric Composition over the Southern Ocean (CAPRICORN) experiment on board the R/V Investigator during a voyage (March-April 2016) in the Australian sector of the Southern Ocean $\left(43^{\circ}-53^{\circ} \mathrm{S}\right)$. ERA-Interim and OAFlux data are further compared with the Southern Ocean Flux Station (SOFS) air-sea flux moored surface float deployed for a year (March 2015-April 2016) at $\sim 46.7^{\circ} \mathrm{S}, 142^{\circ} \mathrm{E}$. The results indicate that ERA-Interim ( 3 hourly at $0.25^{\circ}$ ) and OAFlux (daily at $1^{\circ}$ ) estimate sensible heat flux $H_{s}$ accurately to within $\pm 5 \mathrm{~W} \mathrm{~m}^{-2}$ and latent heat flux $H_{l}$ to within $\pm 10 \mathrm{~W} \mathrm{~m}^{-2}$. ERA-Interim gives a positive bias in $H_{s}$ at low latitudes $\left(<47^{\circ} \mathrm{S}\right)$ and in $H_{l}$ at high latitudes $\left(>47^{\circ} \mathrm{S}\right)$, and OAFlux displays consistently positive bias in $H_{l}$ at all latitudes. No systematic bias with respect to wind or rain conditions was observed. Although some differences in the bulk flux algorithms are noted, these biases can be largely attributed to the uncertainties in the observations used to derive the flux products.
\end{abstract}

\section{Introduction}

The poor knowledge of surface heat fluxes over the Southern Ocean contributes to large uncertainty in the global surface heat and ocean heat budget closure (Josey et al. 1999; Fasullo and Trenberth 2008). The current goal set by the global climate community is to achieve global surface net flux accuracy of $\pm 10 \mathrm{~W} \mathrm{~m}^{-2}$ at a monthly resolution (Fairall et al. 2010), which implies determining fluxes accurately to within $5 \mathrm{~W} \mathrm{~m}^{-2}$ at 3-6-h time resolution and $1^{\circ}$ spatial resolution (Curry et al. 2004). Several global satellite-derived flux products have been released in the past; however, substantial disagreement among them has been reported over the

Corresponding author: Vidhi Bharti, vidhi.bharti@monash.edu
Southern Ocean. The satellite products capture the spatiotemporal patterns accompanied with large variances $\left(15-25 \mathrm{~W} \mathrm{~m}^{-2}\right)$ and substantial differences in the spatiotemporal distribution of fluxes (annual mean for latent heat flux $H_{l}$ of $54-69 \mathrm{~W} \mathrm{~m}^{-2}$ and from -0.2 to $21 \mathrm{~W} \mathrm{~m}^{-2}$ for sensible heat flux $H_{s}$ ) (Liu et al. 2011; $\mathrm{Yu}$ et al. 2011). Further, reanalysis products perform poorly with biases reported as high as $100 \mathrm{~W} \mathrm{~m}^{-2}$ on any given day over the Southern Ocean (Dong et al. 2007). Calibration uncertainties in satellite instruments, regional biases in bulk variables, inconsistencies in transfer coefficients of bulk algorithms and large sampling errors due to unique conditions have been cited as potential sources of errors. The large biases in the energy budget of the Southern Hemisphere in reanalysis products have also been linked to a poor simulation 
of clouds (Trenberth and Fasullo 2010). Further, the impact of mesoscale oceanic eddies on the surface heat budget is yet to be fully resolved over the Southern Ocean (Villas Bôas et al. 2015; Frenger et al. 2013). The acquisition of additional high-quality in situ observationsvia implementation of moorings and voluntary observing ships-and intercomparison of flux products for the improvement of surface flux estimates over high-latitude oceans have been recommended (Bourassa et al. 2013; Gille et al. 2010). There is a dearth of in situ observations over the Southern Ocean region due to its remote location and challenging environment. The region poses severe logistical challenges; hence, conducting frequent dedicated experiments using sensitive instruments employed for flux measurements on board research vessels is an expensive and challenging task. Therefore, the in situ data obtained during these occasional experiments must be employed to reduce biases in routine ship observations that act as inputs to satellite and reanalyses products.

Two flux products available over the Southern Ocean-the combined satellite-reanalyses dataset, Objectively Analyzed Air-Sea heat Fluxes (OAFlux) project at the Woods Hole Oceanographic Institution (Yu et al. 2008) and the European Centre for MediumRange Weather Forecasts (ECMWF) interim reanalysis (ERA-Interim) flux estimates (Dee et al. 2011) have previously been examined for global oceans (Herman 2015). The OAFlux is reported to be in reasonable agreement with ship-based climatology and buoys $(5 \%$ average) due to improved estimations of flux-related input variables over global oceans (Jiang et al. 2012; Yu et al. 2004, 2007; Yu and Weller 2007). Previous studies have identified ERA-Interim heat flux estimates and the algorithm as one of the least problematic over the global oceans (Brunke et al. 2003, 2011; Lindsay et al. 2014). However, the performance of ERA-Interim and OAFlux could not be fully assessed over the Southern Ocean owing to the absence of any ground reference dataset.

The Clouds, Aerosols, Precipitation, Radiation, and Atmospheric Composition over the Southern Ocean (CAPRICORN), phase 1, experiment was carried out during 13 March-15 April 2016 in the Australian sector of the Southern Ocean by the R/V Investigator. The primary objectives were to study clouds, precipitation, atmospheric composition, surface energy budget, and biogeochemistry in the Southern Ocean (Mace and Protat 2018). The voyage sampled one cyclonic eddy (cold core) for 6 days and one anticyclonic (warm core) eddy for 4 days in the Antarctic Circumpolar Current and encountered several extratropical cyclones. One of the principal aims of the project was to acquire high-quality direct flux observations using the National Oceanic and Atmospheric Administration Physical Sciences Division (NOAA/PSD) flux system to validate those derived by the bulk aerodynamic approach, as well as satellite-based and reanalysis products. The bulk fluxes were calculated by the Coupled OceanAtmosphere Response Experiment (COARE) bulk algorithm (Fairall et al. 1996b), a state-of-the-art approach for calculating turbulent fluxes over the open oceans in recent years. Although initially developed for the tropical oceans, the model has been progressively revised for varying wind-wave conditions in the tropics and midlatitude oceans (Brunke et al. 2003; Edson et al. 2013; Fairall et al. 2003).

In addition, a large moored surface float, the Southern Ocean Flux Station (SOFS), has been deployed since 2010 as part of the Australian Integrated Marine Observing System (IMOS) Southern Ocean Time Series project, which has been used to study fluxes in the Southern Ocean previously (Schulz et al. 2011, 2012). A 13-month deployment covering from March 2015 to April 2016 is used in this study.

The objective of the current study is to evaluate the accuracy of flux products on a variable spatiotemporal scale over the Australian sector of the Southern Ocean against the high-quality in situ observations. It is to be noted that ERA-Interim and OAFlux products are gridded flux products; therefore, these flux values are averaged over the grid containing the in situ point measurements. While we acknowledge this disparity between spatiotemporal resolutions of studied flux products, it should not lead to atypical results. An evaluation of the physical processes that underpin the observed flux characteristics is being addressed in a separate study (Bharti et al. 2018, manuscript submitted to J. Geophys. Res. Atmos.). Thus, this paper compares the surface $H_{s}$ and $H_{l}$ (radiative fluxes not included) obtained from the CAPRICORN experiment and SOFS moored surface float with those estimated by OAFlux, ERAInterim, and the routine R/V Investigator ship observations collected using standard instruments as part of IMOS. The R/V Investigator routine sensor data are supplied to the global telecommunication system (GTS) and hence are assimilated into OAFlux and ERAInterim. By contrast, CAPRICORN and SOFS are not supplied to the GTS and remain independent of global datasets that ingest from GTS.

\section{Bulk parameterization algorithms}

All of the bulk parameterization algorithms are based on the Monin-Obukhov similarity theory (MOST), with the turbulent fluxes given by 


$$
\begin{gathered}
\tau=\rho C_{D}\left(U_{10}-U_{0}\right)\left|U_{10}-U_{0}\right|, \\
H_{s}=\rho c_{p} C_{H}\left(\theta_{10}-\theta_{0}\right)\left|U_{10}-U_{0}\right|, \quad \text { and } \\
H_{l}=\rho L_{v} C_{E}\left(q_{10}-q_{0}\right)\left|U_{10}-U_{0}\right|,
\end{gathered}
$$

where $\tau$ indicates wind stress; $\rho$ and $c_{p}$ are the density and isobaric specific heat of air, respectively; $L_{v}$ is the latent heat of vaporization; $\theta$ is the potential temperature; $U$ is wind speed; $q$ is air specific humidity; and transfer coefficients for momentum (drag coefficient), sensible heat (Stanton number), and latent heat (Dalton number) at 10 -m height are $C_{D}, C_{H}$, and $C_{E}$, respectively. The subscript 0 indicates the value at the interface; the subscript 10 indicates the value at $10-\mathrm{m}$ height.

In COARE 3.5, the transfer coefficients for heat and moisture are assumed the same. However, the transfer coefficients are derived from profile functions that in turn are affected by surface roughness, atmospheric stability, wind speed, sea state, and precipitation. Since these transfer coefficients are still being improved over midlatitudes and strong wind regimes, these bulk fluxes are not free from biases. Disagreement in the ship- and buoy-based transfer coefficients has also been noted in previous studies (e.g., Edson 2015). The input parameters have been progressively improved and corrected in the model. The details of the advent, progression and corrections in COARE bulk parameterization model are discussed in Fairall et al. (2003), Bradley and Fairall (2006), and Fairall et al. (1996b).

\section{Datasets}

\section{a. Surface observations}

\section{1) R/V INVESTIGATOR 2016 CRUISE}

The atmospheric and oceanic parameters were measured with the NOAA/PSD flux system (turbulence variables sampled at $10 \mathrm{~Hz}$ and others at $1 \mathrm{~Hz}$ ) on board the ship. The voyage itself was one of its first efforts to conduct such an experiment in the Australian sector of the Southern Ocean. A cold eddy was located at approximately $146.01^{\circ} \mathrm{E}, 50.37^{\circ} \mathrm{S}$ (dimensions roughly $141 \mathrm{~km} \times 111 \mathrm{~km}$ ) and was sampled for 6 days starting from 30 March to 5 April 2016. A warm eddy was also located as a part of a forming meander (roughly $123 \mathrm{~km}$ wide) and was sampled for approximately 4 days starting from 6 to 10 April 2016. These eddies (Fig. 1) were identified using a spatial map of average global sea level anomalies. During the voyage, six extratropical cyclones were also encountered that caused sudden shifts in wind speed, wind direction, precipitation, and sea-state conditions. The details of identification and description of the cold front and warm sector are discussed in (Bharti et al. 2018, manuscript submitted to J. Geophys. Res. Atmos.).

Although the cruise had to endure strong winds (up to $22 \mathrm{~ms}^{-1}$ ) and sea conditions (wave height up to $8 \mathrm{~m}$ ), altogether the instruments functioned well, resulting in a very high-quality observational dataset (Bariteau et al. 2018). However, $\sim 48 \%$ of the flux values obtained by the direct eddy covariance system had to be discarded during preliminary quality control. The bulk fluxes were calculated using the COARE 3.5 bulk model and were compared with filtered direct flux values. Overall, the bulk flux values correlate well $(>95 \%$; $p$ value close to zero) with direct flux observations at an hourly scale during the voyage (Figs. $2 \mathrm{a}$ and $2 \mathrm{~b}$ ). The detailed discussion on the direct and bulk fluxes during the R/V Investigator 2016 voyage can be found in Bharti et al. (2018, manuscript submitted to J. Geophys. Res. Atmos.). Thus, COARE 3.5 bulk fluxes (hereinafter referred to as CAPRICORN fluxes) are used as in situ observations for the validation of other flux products in the present paper. The CAPRICORN fluxes are converted to daily, 3-hourly, and hourly fluxes to be compared with OAFlux, ERA-Interim, and IMOS fluxes, respectively.

\section{2) IMOS ROUTINE BULK FLUXES}

The IMOS gathered the routine ship observations during the $\mathrm{R} / \mathrm{V}$ Investigator voyage alongside NOAA/PSD flux observations. After the Bureau of Meteorology quality control procedure, momentum and heat fluxes were calculated using the COARE 3.0 bulk model with these observations. There are significant gaps in the data, however, for two reasons: First, the system failed to transmit observations from the ship to the shore from 14 to 23 March 2016. Second, a large part of IMOS observations attributed to poor sampling conditions or instrument performance were omitted during preliminary quality control. Hence, usable data are available only from 24 March to 15 April 2016 (reconstructed to hourly estimates for comparison purpose). Overall, $\sim 49 \%$ of the reconstructed hourly data remain missing. The data availability for IMOS Investigator data is shown in Fig. 1 with respect to the ship track.

\section{3) SOFS BUOY}

The SOFS is the long-term air-sea flux moored surface float deployed intermittently since 2010 near $46.7^{\circ} \mathrm{S}, 142^{\circ} \mathrm{E}$ (shown in Fig. 1) for IMOS. Here, we use SOFS data acquired over the period from March 2015 to April 2016. The buoy provides near-real-time surface meteorological and ocean observations, and radiative components continuously at the 1-min sampling rate. 


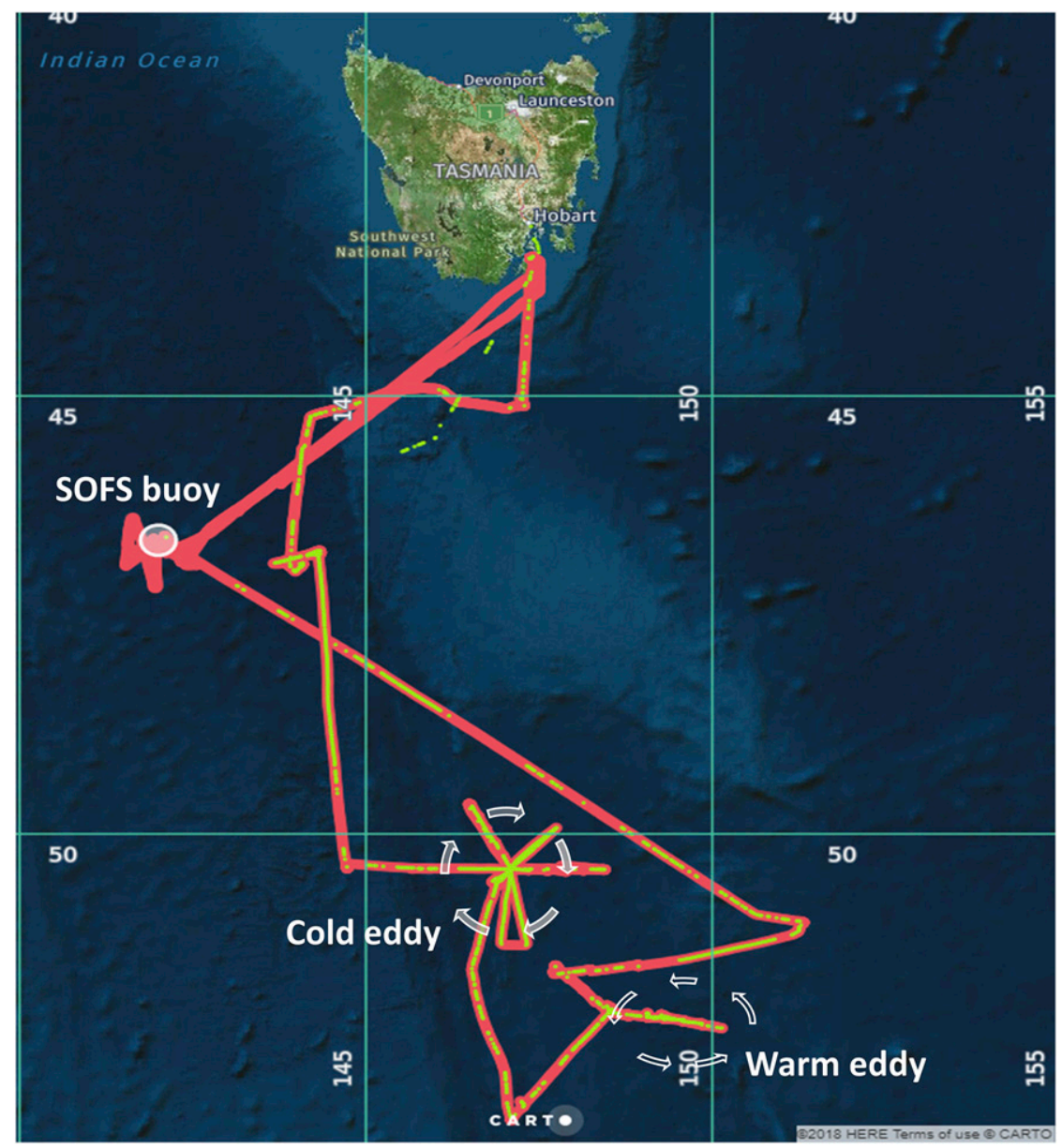

FIG. 1. the R/V Investigator cruise track in March-April 2016 with highlighted data availability of IMOS routine observations (yellow) as compared with NOAA/PSD measurements (red). The location of the SOFS buoy $\left(\sim 46.7^{\circ} \mathrm{S}, 142^{\circ} \mathrm{E}\right)$ is shown with a circle. This map was developed using CartoDB open source software and the HERE base map.

Momentum and heat fluxes are calculated using the COARE 3.5 bulk model after quality control has been applied.

\section{b. Surface flux products}

\section{1) OAFLUX}

The OAFlux project provides heat fluxes for the global ice-free ocean basins. These heat fluxes are computed using the COARE 3.0 bulk flux algorithm following the construction of improved estimates of surface meteorological variables from a blending of satellite retrievals and three atmospheric reanalyses products-NCEP1, NCEP2, and ERA-40 (Yu et al. 2008). The satellite wind speed comes from three inputspassive radiometers Special Sensor Microwave Imager (SSMI), Advanced Microwave Scanning Radiometer for Earth Observing System (AMSR-E), and QuikSCAT.
Near-surface humidity is derived from SSMI column water vapor retrievals (Chou et al. 2003) and height adjusted to 2-m using the COARE 3.0 algorithm. SST data are derived from NOAA optimum interpolation (Reynolds et al. 2007). The third version of the OAFlux product, available for 32 years (1985present) on a daily time scale at $1^{\circ}$-resolution grid, has been employed in the paper. The pixels are extracted on the basis of the ship track and buoy location at the daily scale for comparison with cruise and buoy, respectively.

\section{2) ERA-INTERIM REANALYSIS PRODUCT}

The ERA-Interim reanalysis model estimates timeintegrated surface sensible and latent heat fluxes as accumulated from the beginning of the forecast for every 3-h window (Balsamo et al. 2015). For this study, the forecast fluxes are obtained for every 3 -h with initial 

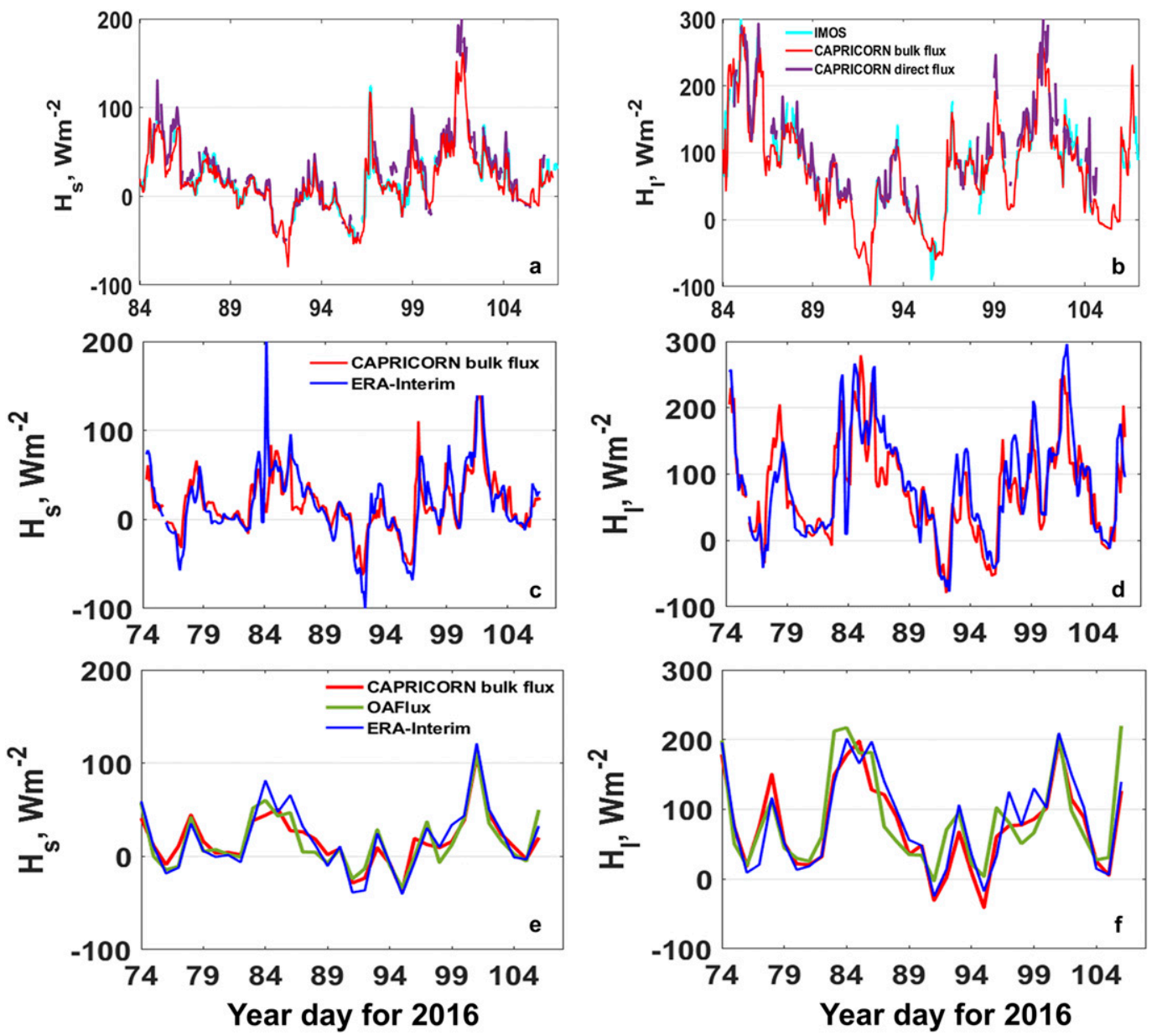

FIG. 2. Comparison of time series of (left) sensible heat flux $H_{s}$ and (right) latent heat flux $H_{l}$ for (a),(b) CAPRICORN fluxes with IMOS routine observations (only available from 24 Mar to 15 Apr 2016) at an hourly scale, (c),(d) the same but with ERA-Interim at a 3-hourly scale, and (e),(f) the same but with OAFlux at daily scale during the R/V Investigator voyage over 13 Mar-15 Apr 2016.

conditions starting from $0000 \mathrm{UTC}$ at $0.25^{\circ}$ resolution. For comparison with cruise and buoy data, grids are extracted relative to the ship track and buoy location, respectively. The surface heat fluxes are computed using a first-order $K$-diffusion closure in the surface layer and are calculated based on the bulk formulation where the transfer coefficients are estimated in terms of profile functions in accordance with the MOST (Beljaars 1998; ECMWF 2015a).

\section{Results}

a. Assessment of IMOS routine fluxes with ship fluxes

The IMOS routine fluxes are compared with the CAPRICORN fluxes. Despite large gaps, IMOS estimates give strong positive correlation $(\sim 0.9$ at $p \approx 0)$ with CAPRICORN fluxes at an hourly scale. The mean $H_{s}$ and $H_{l}$ values for IMOS fluxes are 19.8 and
$83.8 \mathrm{~W} \mathrm{~m}^{-2}$, lying close to the CAPRICORN fluxes at 17.8 and $81.5 \mathrm{~W} \mathrm{~m}^{-2}$, respectively, as shown in Table 1 and Fig. 2a. Further, it gives a slightly lower mean error $\left(2 \mathrm{~W} \mathrm{~m}^{-2}\right)$ and much lower root-mean-square error (RMSE) $\left(9 \mathrm{~W} \mathrm{~m}^{-2}\right)$ for $H_{s}$ values as compared with the same for $H_{l}$ values ( 2.2 and $19 \mathrm{~W} \mathrm{~m}^{-2}$, respectively). However, $H_{s}$ has higher relative error or percent bias $(11.7 \%)$ as compared with $H_{l}$ values $(2.79 \%)$.

IMOS fluxes are compared with CAPRICORN fluxes over the eddies. IMOS gives a positive bias of $1.73 \mathrm{~W} \mathrm{~m}^{-2}$ in $H_{s}$ and $1.97 \mathrm{~W} \mathrm{~m}^{-2}$ in $H_{l}$ over the warm eddy but positive and small negative biases of 1.34 and $-0.45 \mathrm{~W} \mathrm{~m}^{-2}$ in $H_{s}$ and $H_{l}$ values, respectively, over the cold eddy. Overall, RMSE in $H_{s}$ increases over eddies $\left(11.60 \mathrm{~W} \mathrm{~m}^{-2}\right.$ over cold eddy and $9.27 \mathrm{~W} \mathrm{~m}^{-2}$ over warm eddy) but decreases in $H_{l}\left(17.52 \mathrm{~W} \mathrm{~m}^{-2}\right.$ over cold eddy and $15.10 \mathrm{~W} \mathrm{~m}^{-2}$ over warm eddy) when compared with RMSEs of the overall voyage. On average, the 
TABLE 1. Error statistics for $H_{s}$ and $H_{l}$ at given time scales for the R/V Investigator voyage. CAPRICORN bulk fluxes are extracted for the given products and their respective time periods and resolutions. Missing values are excluded prior to comparison. The fluxes are defined as positive upward. The unit is watts per meter squared for all statistics except the percent bias.

\begin{tabular}{|c|c|c|c|c|c|c|}
\hline & \multicolumn{2}{|c|}{$\begin{array}{l}\text { Hourly IMOS (24 } \\
\text { Mar-15 Apr 2016) }\end{array}$} & \multicolumn{2}{|c|}{$\begin{array}{l}\text { 3-hourly ERA-Interim } \\
\text { (14 Mar-15 Apr 2016) }\end{array}$} & \multicolumn{2}{|c|}{$\begin{array}{l}\text { Daily OAFlux (14 } \\
\text { Mar-15 Apr 2016) }\end{array}$} \\
\hline & $H_{s}$ & $H_{l}$ & $H_{s}$ & $H_{l}$ & $H_{s}$ & $H_{l}$ \\
\hline CAPRICORN flux mean & 17.76 & 81.50 & 16.59 & 75.83 & 16.77 & 76.94 \\
\hline Product mean & 19.84 & 83.78 & 17.56 & 83.12 & 16.44 & 86.23 \\
\hline CAPRICORN flux std dev $(\sigma)$ & 29.99 & 65.09 & 32.15 & 72.50 & 26.73 & 63.37 \\
\hline Product $\sigma$ & 30.40 & 68.62 & 41.48 & 77.85 & 30.35 & 67.86 \\
\hline Mean error, i.e., bias & 2.07 & 2.27 & 0.97 & 7.29 & -0.32 & 9.28 \\
\hline Relative bias, i.e., percent bias (\%) & 11.7 & 2.79 & 5.88 & 9.61 & -1.95 & 12.07 \\
\hline RMSE & 9.06 & 19.23 & 24.07 & 42.90 & 12.94 & 33.54 \\
\hline
\end{tabular}

IMOS routine fluxes slightly overestimate heat fluxes as compared with CAPRICORN fluxes.

\section{b. Assessment of ERA-Interim with ship and buoy fluxes}

ERA-Interim 3-hourly fluxes are compared with CAPRICORN fluxes for March-April 2016 (Fig. 2) and at daily time scale with SOFS (Fig. 3) for March 2015-April 2016. ERA-Interim estimates $H_{l}$ with relative bias of less than $5 \%$, but it overestimates $H_{s}(>35 \%$ bias $)$ when compared with buoy fluxes (Table 2). However, when compared with CAPRICORN fluxes, it performs worse for $H_{l}(\sim 10 \%$ relative bias $)$ than $H_{s}(\sim 6 \%$ relative bias) as seen in Table 1. ERA-Interim also shows larger variance in fluxes when compared to CAPRICORN fluxes.

The product might perform very differently over different latitudes. Hence, to analyze this hypothesis, ERA-Interim 3-hourly fluxes are analyzed for lower and higher latitudes. Here, the location of the SOFS buoy at $\sim 47^{\circ} \mathrm{S}$ is taken as the dividing line with $>47^{\circ} \mathrm{S}$ considered higher latitudes and vice versa. ERAInterim gives positive bias $\left(1.6 \mathrm{~W} \mathrm{~m}^{-2}\right)$ and higher relative bias $(8.3 \%)$ in $H_{s}$ when the ship is at lower latitudes $\left(<47^{\circ} \mathrm{S}\right)$. ERA-Interim gives higher positive bias $\left(14.4 \mathrm{~W} \mathrm{~m}^{-2}\right)$ and higher relative bias $(24.5 \%)$ in $H_{l}$ when the ship is at higher latitudes $\left(>47^{\circ} \mathrm{S}\right)$. Overall, ERA-Interim gives higher uncertainty in $H_{s}$ at lower latitudes as noted through the comparison with both ship and buoy fluxes whereas at higher latitudes larger uncertainty is recorded in $H_{l}$. Further, ERAInterim flux values are compared with CAPRICORN fluxes using mean error (or bias) statistic during pre-, mid-, and postcyclonic conditions during the traversal of six extratropical cyclones. ERA-Interim yields a higher positive bias in $H_{l}\left(\sim 7.7 \mathrm{~W} \mathrm{~m}^{-2}\right)$ than in $H_{s}\left(\sim-1.8 \mathrm{~W} \mathrm{~m}^{-2}\right)$ in the prefrontal conditions. However, bias becomes negative for $H_{s}$ (approximately $\left.-10 \mathrm{~W} \mathrm{~m}^{-2}\right)$ and decreases for $H_{l}\left(\sim 2.6 \mathrm{~W} \mathrm{~m}^{-2}\right)$ during midcyclone conditions. The bias again becomes small for $H_{s}\left(\sim-3.1 \mathrm{~W} \mathrm{~m}^{-2}\right)$ but continues to decrease for $H_{l}$ (approximately $-7.2 \mathrm{~W} \mathrm{~m}^{-2}$ ) in postfrontal conditions.

The product performance is also evaluated with respect to increasing wind speeds ranging from 1 to $20 \mathrm{~m} \mathrm{~s}^{-1}$ and for rain conditions with respect to both CAPRICORN and buoy fluxes. For the buoy, the average rain rate was recorded as $0.02 \mathrm{~mm} \mathrm{~h}^{-1}$ for the given time period. Low rain rate $\left(<1 \mathrm{~mm} \mathrm{~h}^{-1}\right)$ was observed more than $60 \%$ of the time. Further, independent analyses of ERA-Interim with respect to the voyage and buoy reveal no systematic bias in ERAInterim fluxes with respect to either wind speeds or rain rates.

A few previous studies have observed a strong localized variability like bull's-eye features in ECMWF fluxes and specific humidity in the tropical Pacific Ocean (Tomita and Kubota 2006; Josey et al. 2014). The reasons were attributed to problems in reanalysis model physics and assimilation schemes. However, no such localized variability in either fluxes or meteorological variables is noticed in ERA-Interim over our study region.

\section{c. Assessment of OAFlux with ship and buoy fluxes}

The OAFlux data are available as daily means, so the sample size is small (33 points) for the voyage. A strong positive correlation $(\sim 0.9 ; p$ value close to zero) is found for both $H_{s}$ and $H_{l}$ when compared with CAPRICORN bulk fluxes. There is a better agreement (bias of $-0.3 \mathrm{~W} \mathrm{~m}^{-2}$ ) in $H_{s}$ than in $H_{l}$ (bias of $9.3 \mathrm{~W} \mathrm{~m}^{-2}$ ) between OAFlux and CAPRICORN fluxes as seen in Table 1. The error statistics have been calculated after the gridwise extraction of the daily flux data relative to the ship track. Further, for comparison purpose, ERA-Interim fluxes are extracted at $1^{\circ}$ resolution on a daily time scale and are plotted alongside OAFlux fluxes as shown in Figs. 2e and $2 \mathrm{f}$. 

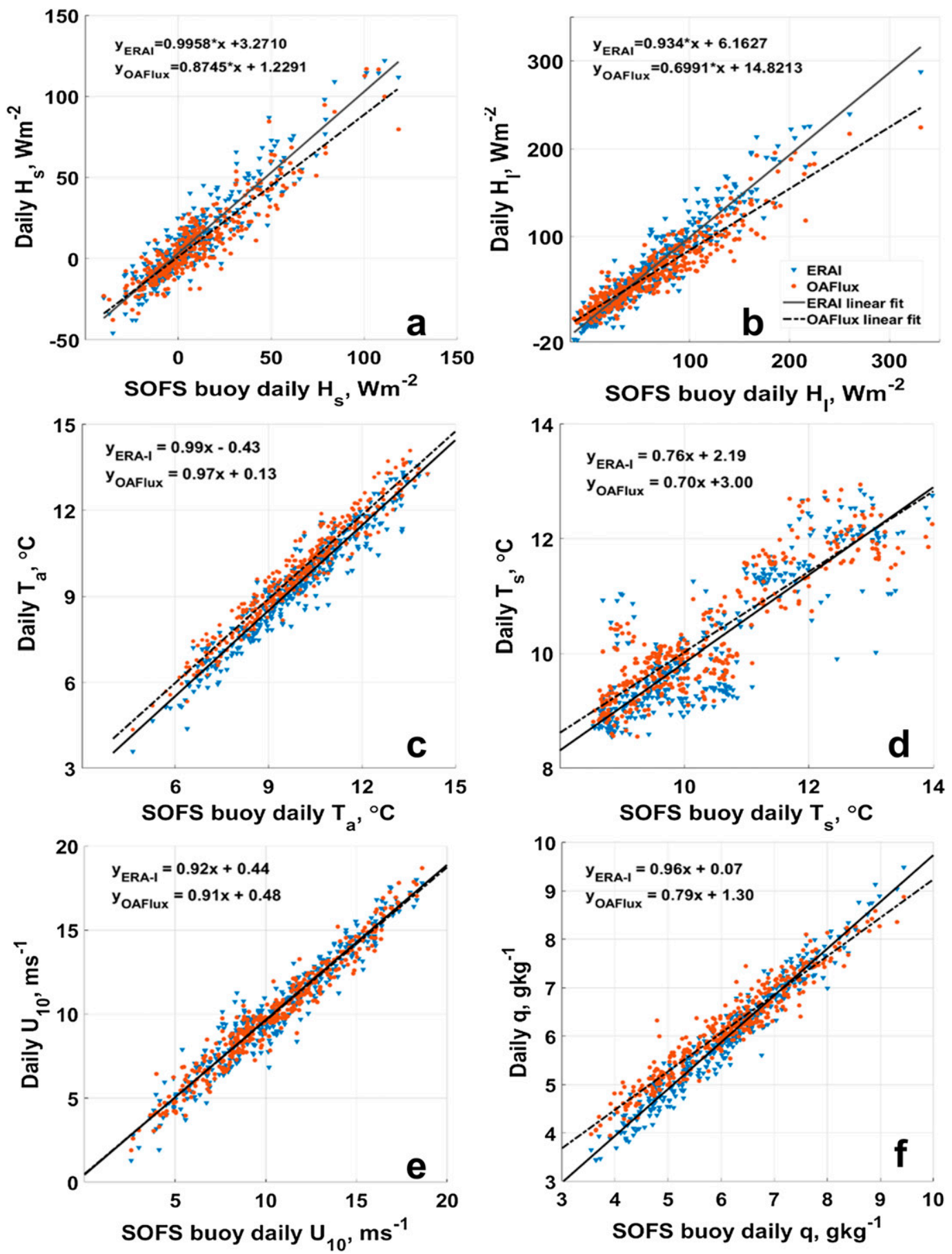

FIG. 3. Scatterplots of daily ERA-Interim, OAFlux products with SOFS buoy data for (a) $H_{s}$, (b) $H_{l}$, (c) $T_{a}$, (d) $T_{s}$, (e) $U_{10}$, and (f) $q$ for 12 months over 2015-16.

ERA-Interim underestimates $H_{s}$ (bias of $-0.66 \mathrm{~W} \mathrm{~m}^{-2}$ ) and overestimates $H_{l}$ values (bias $\sim 20 \mathrm{~W} \mathrm{~m}^{-2}$ ). Altogether, OAFlux performs better than ERA-Interim at the daily resolution.

When compared with buoy fluxes, OAFlux underestimates (bias of approximately $-7 \mathrm{~W} \mathrm{~m}^{-2}$ ) $H_{l}$ but gives near-accurate estimates of $H_{s}$. Conclusively, OAFlux consistently gives a higher-magnitude bias in $H_{l}$ when compared with either ship or buoy fluxes. A recent study over the global region also reports systematic bias in $H_{l}$ values in OAFlux (Tomita et al. 2019). However, no conclusive systematic bias is observed in OAFlux values 
TABLE 2. Error statistics for $H_{s}$ and $H_{l}$ for hourly SOFS buoy, 3-hourly ERA-Interim, and daily OAFlux products at daily time scale. All units are watts per meter squared except the percent bias.

\begin{tabular}{|c|c|c|c|c|c|c|}
\hline & \multicolumn{2}{|c|}{ SOFS buoy } & \multicolumn{2}{|c|}{ ERA-Interim } & \multicolumn{2}{|c|}{ OAFlux } \\
\hline & $H_{s}$ & $H_{l}$ & $H_{s}$ & $H_{l}$ & $H_{s}$ & $H_{l}$ \\
\hline Mean & 9.18 & 64.04 & 12.41 & 65.98 & 9.261 & 59.59 \\
\hline$\sigma$ & 25.37 & 53.71 & 27.10 & 52.63 & 24.10 & 40.22 \\
\hline Mean error, i.e., bias & & & 3.23 & 1.93 & 0.076 & -4.44 \\
\hline Relative bias, i.e., percent bias (\%) & & & 35.19 & 3.02 & 0.083 & -6.94 \\
\hline RMSE & & & 10.31 & 16.40 & 9.92 & 22.07 \\
\hline
\end{tabular}

with respect to increasing wind speeds when compared with buoy data.

\section{Discussion}

We have compared the average performance of ERAInterim, OAFlux, and IMOS flux products over the Australian sector of the Southern Ocean with respect to bulk fluxes acquired using the NOAA/PSD flux system during a month-long CAPRICORN experiment in March-April 2016 and the 13-month (2015-16) SOFS data. The comparison is performed for lower latitudes $\left(<47^{\circ} \mathrm{S}\right)$ with both buoy and ship fluxes and for higher latitudes $\left(>47^{\circ} \mathrm{S}\right)$ with ship fluxes with the location of the buoy at $\sim 47^{\circ} \mathrm{S}$ as the dividing line.

The comparison reveals for ERA-Interim large positive biases in $H_{l}\left(\sim 14.43 \mathrm{~W} \mathrm{~m}^{-2}\right)$ at higher latitudes and in $H_{s}\left(\sim 1.64 \mathrm{~W} \mathrm{~m}^{-2}\right)$ at lower latitudes. A similar result was obtained by Brunke et al. (2011) who observed that ERA-Interim performs better for $H_{l}$ than for $H_{s}$ in the tropics and midlatitudes. In contrast to our results, Lindsay et al. (2014) observed an underestimation in $H_{l}$ but overestimation in $H_{s}$ over the Arctic region $\left(>65^{\circ} \mathrm{N}\right)$. Further, the RMSEs noted in ERA-Interim fluxes are relatively higher $\left(\sim 24 \mathrm{~W} \mathrm{~m}^{-2}\right.$ in $H_{s}$ and $\sim 43 \mathrm{~W} \mathrm{~m}^{-2}$ in $\left.H_{l}\right)$ at higher latitudes but lower $\left(<20 \mathrm{~W} \mathrm{~m}^{-2}\right.$ for both fluxes) at lower latitudes over the analysis region as compared with the previous findings, which estimated RMSEs in heat fluxes of order $\sim 20 \mathrm{~W} \mathrm{~m}^{-2}$ over the land regions (Balsamo et al. 2015; Szczypta et al. 2011).

The daily OAFlux gives a higher bias in $H_{l}$ as compared to $H_{s}$, which is very close (average within $\pm 0.5 \mathrm{~W} \mathrm{~m}^{-2}$ ) to the ship and buoy averages. It overestimates (bias of $\left.8.75 \mathrm{~W} \mathrm{~m}^{-2}\right) H_{l}$ at higher latitudes but underestimates (bias of $-3.81 \mathrm{~W} \mathrm{~m}^{-2}$ ) at lower latitudes. However, the sample size is not significant (16 points) for high-latitude regions. These findings are in agreement with previous results that observed OAFlux behavior over the different oceans (Brunke et al. 2011; Santorelli 2011; Tomita et al. 2016). However, OAFlux gives larger bias in magnitude over the Southern Ocean region examined in our study as compared with the global oceans $\left(0.04 \mathrm{~W} \mathrm{~m}^{-2}\right.$ for $H_{s}$ and $0.98 \mathrm{~W} \mathrm{~m}^{-2}$ for $H_{l}$, respectively; Yu et al. 2008).

All of the bulk parameterization algorithms use Eqs. (1)-(3) as the base, yet the estimated turbulent fluxes differ because of differences in either the input bulk variables or the physical parameterizations used for various key processes. The desired accuracy of the mean (or bias) under nominal conditions has been determined to be within $0.2 \mathrm{~m} \mathrm{~s}^{-1}$ for wind speed, $0.2^{\circ} \mathrm{C}$ for air temperature, $0.1^{\circ} \mathrm{C}$ for sea surface temperature, and $0.3 \mathrm{~g} \mathrm{~kg}^{-1}$ for specific humidity to attain $\pm 10 \mathrm{~W} \mathrm{~m}^{-2}$ accuracy in monthly surface net heat flux (Bradley and Fairall 2006; Weller et al. 2004). Tables 3 and 4 summarize these four input variables-air temperature $T_{a}$, skin sea surface temperature $T_{s}$, specific humidity $q$, and $10-\mathrm{m}$ wind speed $U_{10}$ with respect to ship and buoy observations.

ERA-Interim has the highest uncertainties in $T_{a}$ (bias of $-0.5^{\circ} \mathrm{C}$ ) when compared with buoy observations and in $T_{s}$ (bias of $-0.4^{\circ} \mathrm{C}$ ) when compared with ship observations. However, ERA-Interim has lower bias in $U_{10}$ but higher bias in $T_{s}$ over this Southern Ocean region when compared with biases noted in the Drake Passage

TABLE 3. Mean and standard deviation of air temperature $T_{a}$, sea surface temperature $T_{s}$, specific humidity $q$, and 10 -m wind speed $U_{10}$ for the given datasets on the given spatiotemporal scales during the $\mathrm{R} / \mathrm{V}$ Investigator voyage.

\begin{tabular}{|c|c|c|c|c|c|c|}
\hline & $\begin{array}{c}\text { Hourly CAPRICORN } \\
\text { flux data }\end{array}$ & Hourly IMOS & $\begin{array}{c}\text { 3-hourly } \\
\text { CAPRICORN flux }\end{array}$ & $\begin{array}{l}\text { 3-hourly } \\
\text { ERA-Interim }\end{array}$ & $\begin{array}{c}\text { Daily } \\
\text { CAPRICORN flux }\end{array}$ & Daily OAFlux \\
\hline$T_{a}\left({ }^{\circ} \mathrm{C}\right)$ & $9.23 \pm 2.90$ & $9.05 \pm 2.86$ & $10.19 \pm 2.94$ & $10.18 \pm 2.87$ & $10.24 \pm 2.73$ & $11.14 \pm 2.60$ \\
\hline$T_{s}\left({ }^{\circ} \mathrm{C}\right)$ & $10.63 \pm 3.25$ & $10.54 \pm 3.21$ & $11.57 \pm 3.26$ & $11.16 \pm 2.92$ & $11.63 \pm 3.14$ & $12.07 \pm 2.88$ \\
\hline$q\left(\mathrm{~g} \mathrm{~kg}^{-1}\right)$ & $5.68 \pm 1.40$ & $5.69 \pm 1.48$ & $6.20 \pm 1.64$ & $6.30 \pm 1.52$ & $6.20 \pm 1.39$ & $6.65 \pm 1.04$ \\
\hline$U_{10}\left(\mathrm{~m} \mathrm{~s}^{-1}\right)$ & $11.59 \pm 3.51$ & $11.99 \pm 3.52$ & $10.52 \pm 3.74$ & $10.76 \pm 3.76$ & $10.54 \pm 3.06$ & $10.41 \pm 3.30$ \\
\hline
\end{tabular}


TABLE 4. Mean and standard deviation of $T_{a}, T_{s}, q$, and $U_{10}$ for the given datasets as compared with the SOFS buoy on a daily time scale for a year in 2015-16.

\begin{tabular}{lrrr}
\hline \hline & SOFS buoy & ERA-Interim & \multicolumn{1}{c}{ OAFlux } \\
\hline$T_{a}\left({ }^{\circ} \mathrm{C}\right)$ & $9.89 \pm 1.82$ & $9.38 \pm 2.0$ & $9.77 \pm 1.82$ \\
$T_{s}\left({ }^{\circ} \mathrm{C}\right)$ & $10.39 \pm 1.36$ & $10.14 \pm 1.20$ & $10.30 \pm 1.07$ \\
$q\left(\mathrm{~g} \mathrm{~kg}^{-1}\right)$ & $6.13 \pm 1.17$ & $6.00 \pm 1.28$ & $6.17 \pm 0.96$ \\
$U_{10}\left(\mathrm{~m} \mathrm{~s}^{-1}\right)$ & $9.31 \pm 2.97$ & $10.09 \pm 3.78$ & $10.03 \pm 3.22$ \\
\hline
\end{tabular}

(Jiang et al. 2012). Further, ERA-Interim gives higher bias (in magnitude) in $H_{l}$ than in $H_{s}$ during pre- and postfrontal conditions. This could be due to higher positive biases in $U_{10}$ (bias of $0.7 \mathrm{~m} \mathrm{~s}^{-1}$ ) and $q$ (bias of $0.6 \mathrm{~g} \mathrm{~kg}^{-1}$ ) during postfrontal conditions. The mean bias in $U_{10}$ and $q$ gradually increases from pre- to postfrontal conditions, whereas mean bias is the highest in $T_{a}$ and the lowest in $T_{s}$ during midfrontal conditions. Overall, ERA-Interim performs better than OAFlux for fluxes as well as bulk variables as evident in Fig. 3.

IMOS routine ship observations are closest to NOAA/PSD observations; however, IMOS underestimates $T_{a}$ (mean error of $-0.2^{\circ} \mathrm{C}$ ) and $T_{s}$ (mean error of $-0.1^{\circ} \mathrm{C}$ ), and overestimates $U_{10}$ (mean error of $0.4 \mathrm{~m} \mathrm{~s}^{-1}$ ). OAFlux has high mean errors in $T_{a}\left(0.9^{\circ} \mathrm{C}\right), q\left(0.4 \mathrm{~g} \mathrm{~kg}^{-1}\right)$, and $T_{s}\left(0.4^{\circ} \mathrm{C}\right)$ when compared with ship observations. OAFlux underestimates (bias of $-0.4 \mathrm{~m} \mathrm{~s}^{-1}$ ) $U_{10}$ when compared with buoy observations but gives high overall RMSE of $\sim 0.9 \mathrm{~m} \mathrm{~s}^{-1}$ over the analysis region. Similar results were reported by Yu et al. (2008) who attributed rain as a possible reason for the degradation of SSMI wind speed retrievals.

Figure 4 displays the comparison of monthly fluxes and bulk variables with SOFS buoy data for the March 2015-April 2016 time period along with the desired accuracy of mean. The $H_{s}$ by both products is not within $\pm 5 \mathrm{~W} \mathrm{~m}^{-2}$ during February, March, and November. For $H_{l}$, however, the products are only accurate to within $\pm 10 \mathrm{~W} \mathrm{~m}^{-2}$ for all months except February and March. ERA-Interim consistently underestimates $T_{a}$, whereas both of the products display highest uncertainties in $T_{s}$ and $U_{10}$. Despite agreement for $q$ at a daily scale, the bias is low for mean monthly values for both of the products and falls within the desired level of accuracy. Altogether, the level of accuracy is high for $H_{s}$, and products perform better on average during the winter
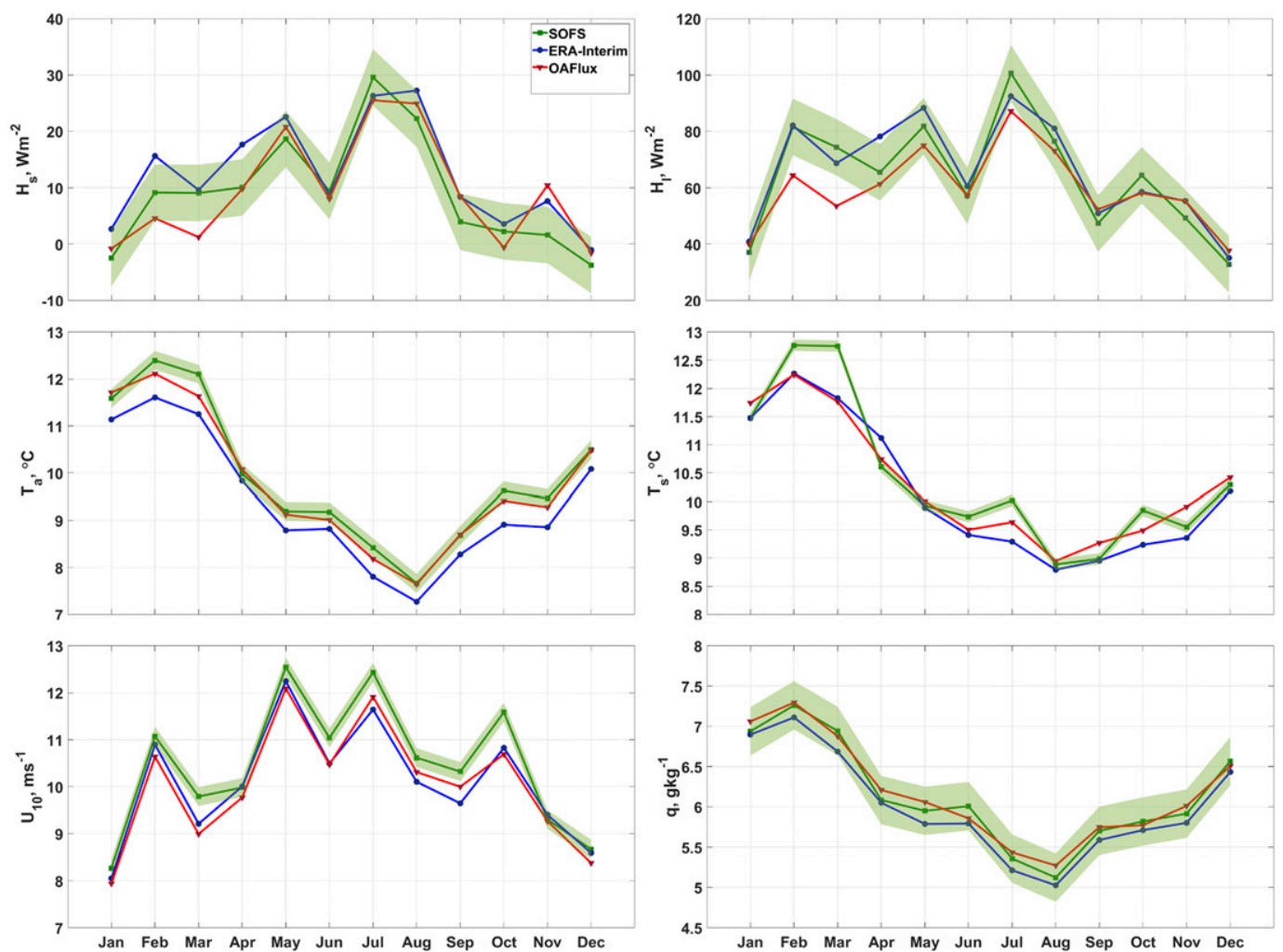

FIG. 4. Mean monthly variation displayed along with target accuracy of mean as shaded area obtained by SOFS buoy, OAFlux, and ERA-Interim products for (top left) $H_{s} \pm 5 \mathrm{~W} \mathrm{~m}^{-2}$, (top right) $H_{l} \pm 10 \mathrm{~W} \mathrm{~m}^{-2}$, (middle left) $T_{a} \pm 0.2^{\circ} \mathrm{C}$, (middle right) $T_{s} \pm 0.1^{\circ} \mathrm{C}$, (bottom left) $U_{10} \pm 0.2 \mathrm{~m} \mathrm{~s}^{-1}$, and (bottom right) $q \pm 0.3 \mathrm{~g} \mathrm{~kg}^{-1}$ for $12 \mathrm{months}$ over 2015-16. 
TABLE 5. The formulations used in the COARE 3.0/3.5 bulk model and ECMWF scheme for the five contributing factors in the parameterizations.

\begin{tabular}{|c|c|c|}
\hline Physical parameterization & COARE $3.0 / 3.5$ model & ECMWF scheme \\
\hline Surface wave spectrum & $\begin{array}{l}\text { Does not use coupled wave model; to model the effect of sea } \\
\text { state and wave age } z_{0}^{\text {rough }} / \gamma=D\left(u_{*} / C_{p}\right)^{2} \text {, where } z_{0}^{\text {rough }} \text { is } \\
\text { the roughness length for rough flow, } \gamma \text { is significant wave } \\
\text { height, } u_{*} \text { is friction velocity, } C_{p} \text { is the phase speed of the } \\
\text { dominant, and } u_{*} / C_{p} \text { is inverse wave age }\end{array}$ & $\begin{array}{l}d F / d t=S=S_{\mathrm{in}}+S_{\mathrm{nl}}+S_{\mathrm{diss}} \text {, where } S_{\mathrm{in}} \\
\text { is generation of waves by wind, } S_{\mathrm{nl}} \text { is } \\
\text { nonlinear four-wave interaction, and } \\
S_{\mathrm{diss}} \text { is dissipation of ocean waves, e.g., } \\
\text { wave breaking }\end{array}$ \\
\hline \multirow[t]{2}{*}{$\begin{array}{l}\text { Roughness length } \\
\text { formulation }\end{array}$} & $\begin{array}{l}\text { Velocity roughness length } z_{0 M}=\alpha_{M}\left(\nu / u_{*}\right)+\alpha_{\mathrm{Ch}}\left(u_{*}^{2} / g\right) \text {, } \\
\text { thermal roughness length } z_{0 H}=\alpha_{H} \nu / u_{*}, \text { and moisture } \\
\text { roughness length } z_{0 Q}=\alpha_{Q} \nu / u_{*}, \\
\alpha_{\mathrm{Ch}}=\left\{\begin{array}{ccc}0.011 & \text { for } \quad S \leq 10 \mathrm{~m} \mathrm{~s}^{-1} \\
0.011+\frac{0.007}{8}(S-10) & \text { for } \quad 10<S \leq 18, S \text { is } \\
0.018 & \text { for } \quad S \geq 18 \mathrm{~m} \mathrm{~s}^{-1}\end{array}\right.\end{array}$ & $\begin{array}{l}\text { Same roughness length equations as in } \\
\text { COARE } 3.5 \text {, but } \alpha_{\mathrm{CH}}=0.018 \text { for the un- } \\
\text { coupled model, } \alpha_{\mathrm{Ch}}=\hat{\alpha} /\left[1-\left(\tau_{w} / \tau\right)\right]^{1 / 2} \\
\text { for the coupled model (wave model) with } \\
\tau_{w} \text { being wave-induced stress and } \tau \text { being } \\
\text { total stress, } \alpha_{M}=0.11, \alpha_{H}=0.40, \\
\alpha_{Q}=0.62 \text {, and kinematic viscosity } \\
\nu=1.5 \times 10^{-5} \mathrm{~m}^{2} \mathrm{~s}^{-1}\end{array}$ \\
\hline & $\begin{array}{l}\text { mean wind speed w.r.t ocean, } \alpha_{M}=0.11, g \text { is } \\
\text { gravitational acceleration, } z_{0 H}=z_{0 Q} ; \text { for COARE } 3.0 \text {, } \\
z_{0 Q}=\min \left(1.1 \times 10^{-4}, 5.5 \times 10^{-5} R_{r}^{-0.6}\right) \text { and } R_{r} \text { is rough- } \\
\text { ness Reynolds number; for COARE } 3.5, z_{0 Q}= \\
\min \left(1.6 \times 10^{-4}, 5.8 \times 10^{-5} R_{r}^{-0.72}\right)\end{array}$ & \\
\hline $\begin{array}{l}\text { Consideration of convective } \\
\text { gustiness }\end{array}$ & $\begin{array}{l}U_{g}=\beta W_{*}=\beta\left[(g / T) w^{\prime} \theta_{v}^{\prime} z_{i}\right]^{1 / 3}, \text { where } W_{*} \text { is convective } \\
\text { velocity scale, } z \text { is depth of the convective boundary layer, } \\
\quad U_{g} \text { is gustiness, and } \beta=1.25\end{array}$ & $\begin{array}{l}\text { Same equation as in COARE, } 3.5 \\
\text { but } \beta=1\end{array}$ \\
\hline $\begin{array}{l}\text { Salinity effect on ocean } \\
\text { surface saturated } \\
\text { humidity }\end{array}$ & $\begin{array}{l}q_{s}=0.98 q_{\mathrm{sat}}\left(T_{s}\right), \text { where } q_{s} \text { is water vapor mixing ratio, } q_{\mathrm{sat}} \text { is } \\
\text { saturation mixing ratio, and } T_{s} \text { is sea surface temperature }\end{array}$ & Same as in COARE \\
\hline $\begin{array}{l}\text { Turbulent exchange coeff } \\
\text { formulation }\end{array}$ & $\begin{array}{l}\text { Total transfer coef } C_{x}=c_{x}^{1 / 2} c_{d}^{1 / 2} \text {, where } x \text { can be } u \text { or } v \text { wind } \\
\text { components, potential temperature } \theta \text {, or water vapor specific } \\
\text { humidity } q \text {, and } c_{x} \text { is the bulk transfer coefficient, with } d \\
\text { being used for wind speed, } c_{x}^{1 / 2}(\xi)=c_{x n}^{1 / 2} /\left[1-\left(c_{x n}^{1 / 2} / \kappa\right) \psi_{x}(\xi)\right] \text {, } \\
\text { with } c_{x n}^{1 / 2}=\kappa / \ln \left(z / z_{0 x}\right), \xi \text { is the MOST stability parameter, } \\
\text { subscript } n \text { refers to neutral }(\xi=0) \text { stability, } \psi_{x} \text { is an } \\
\text { empirical function describing stability dependence of the } \\
\text { mean profile, } z_{0 x} \text { is the roughness length for } x \text {, and } \kappa \text { is von } \\
\text { Kármán's constant }\end{array}$ & Same as in COARE \\
\hline
\end{tabular}

season (May-October). Colbo and Weller (2009) studied the meteorological error propagation through bulk flux formulas. They concluded that sensible heat flux error is dominated by uncertainties in $T_{a}$ and $C_{H}$ whereas latent heat flux error is largely affected by uncertainty in $C_{E}$ and has little dependence on errors in relative (or $q$ ) humidity.

The differences in the parameterizations of the bulk algorithms may also contribute to the differences in the flux estimations. Since both IMOS routine observations and OAFlux evaluate fluxes using the COARE bulk algorithm, it comes down to the differences in the COARE and ECMWF algorithms. Brunke et al. (2002) attributed surface wave spectrums, roughness length formulation, consideration of convective gustiness, salinity effect on ocean surface saturated humidity, and turbulent exchange coefficient formulation as major key differences in the parameterization schemes that contribute significantly to flux variations. Table 5 contrasts these formulations used in the COARE and ECMWF algorithms.
Since these algorithms are based on the MOST theory, the parameterization of transfer coefficients follows the similar routine. Both the algorithms resort to similar parameterizations for salinity effect on ocean surface saturated humidity as well. The cool skin-warm layer diurnal effect in sea surface temperature is also incorporated in both the schemes using the same method (ECMWF 2015a; Fairall et al. 1996a). Despite these similarities, the most obvious difference is in the formulation of roughness lengths, which plays a major role in the formulation of transfer coefficients. The ECMWF calculates a wave-age-dependent Charnock coefficient (Janssen 2008), whereas the COARE 3.5 algorithm calculates the Charnock coefficient on the basis of a wind speeddependent formulation (Edson et al. 2013) as shown in Table 5, which implies a mature sea state in balance with the wind forcing. In the present study, the Charnock coefficient from ECMWF is generally higher (from $\sim 0.95 \times 10^{-2}$ to $\sim 6.44 \times 10^{-2}$ ) than observed values 
(from $1.1 \times 10^{-2}$ to $1.8 \times 10^{-2}$ ) because the determining constant $\hat{\alpha}$ is found by a trial-and-error method (ECMWF 2015b). Further, thermal and moisture roughness lengths in the ECMWF scheme are estimated to be higher by approximately $50 \%-400 \%$ and $130 \%-$ $800 \%$, respectively, as compared with COARE 3.5 bulk values, for the given wind speeds during the $\mathrm{R} / \mathrm{V} I n$ vestigator voyage. This could be one of the reasons for higher sensible and latent heat transfer coefficients in ECMWF scheme leading to overestimation in $H_{s}$ and $H_{l}$. Further, in the COARE 3.5 algorithm, both the thermal and moisture roughness length are equal whereas the moisture roughness length is estimated to be higher in ECMWF. It has been previously observed that the COARE 3.5 wind speed-dependent formulation without wave information agrees well with the observations (Edson et al. 2013). Edson (2008) states a good agreement for the drag coefficient between COARE and ECMWF schemes despite these differences. Further, the comparison of wind speeds including gustiness during the voyage indicates a probable overestimation of wind gustiness by ECMWF as well.

The COARE 3.0 and COARE 3.5 versions only have minor differences (Edson et al. 2013). In COARE 3.5, adjustments were made to wind speed-dependent formulation of Charnock parameter based on a large database of direct covariance stress observations. It caused an increase in wind stress for wind speeds greater than $18 \mathrm{~m} \mathrm{~s}^{-1}$. However, change in wind stress values have no impact on heat flux values. The roughness Reynold number formulation of scalar roughness length was slightly modified to equate both Stanton and Dalton numbers with those in version 3.0.

\section{Conclusions}

We compared the surface heat fluxes obtained from the ERA-Interim reanalysis and the OAFlux hybrid dataset with those measured during the CAPRICORN experiment (with the NOAA/PSD flux system and IMOS routine observations) carried out on board the R/V Investigator (March-April 2016) and by the SOFS buoy deployed for a year (2015-16) in the Australian sector of the Southern Ocean. With the current aim to reconcile surface flux accuracy to within $5 \mathrm{~W} \mathrm{~m}^{-2}$ at 3-6 h resolution, overall, ERA-Interim (3 hourly at $0.25^{\circ}$ ) and OAFlux (daily at $1^{\circ}$ ) estimate sensible heat flux $H_{s}$ accurately to $\pm 5 \mathrm{~W} \mathrm{~m}^{-2}$, but not latent heat flux $H_{l}$. ERA-Interim gives a bias of higher magnitude bias for $H_{s}$ at lower latitudes $\left(<47^{\circ} \mathrm{S}\right)$ and for $H_{l}$ at higher latitudes $\left(>47^{\circ} \mathrm{S}\right)$. Similarly, OAFlux provides good estimates of $H_{s}$ (bias within $\pm 0.5 \mathrm{~W} \mathrm{~m}^{-2}$ ) but consistently gives a higher-magnitude bias (within $\pm 10 \mathrm{~W} \mathrm{~m}^{-2}$ ) in $H_{l}$ across the range of latitudes sampled $\left(44^{\circ}-53^{\circ} \mathrm{S}\right)$. The biases in ERA-Interim heat flux estimates can be attributed to higher bias in $T_{a}$ and $U_{10}$ at lower latitudes and in $T_{s}$ at higher latitudes, whereas OAFlux has high uncertainty in $U_{10}$ at lower latitudes but in $T_{a}$ and $T_{s}$ at higher latitudes.

Other than uncertainties in bulk variables, the ECMWF scheme overestimates roughness lengths and wind gustiness, which might explain the overestimation in heat fluxes. While OAFlux has been noted to agree well with ship-based climatology at seasonal and annual time scale (Yu et al. 2008), the current analysis shows that it can also be used at daily time scale for lower latitudes for the study of heat fluxes and energy budget. However, its application in studying mesoscale systems remains limited due to its coarse spatiotemporal resolution. IMOS routine ship observations overestimate $H_{s}(\sim 11 \%)$ and $H_{l}(\sim 3 \%)$ as compared with the NOAA/PSD flux observations during the voyage. But since these are observations, they are closest to what was observed by the NOAA/PSD system during the R/V Investigator voyage. Conclusively, there is still a need to quantify the uncertainty in measurements and derived fluxes under extreme conditions.

Acknowledgments. This research is supported by the ARC Centre of Excellence for Climate System Science (Grant DP150102894). Authors are thankful to the CSIRO Marine National Facility (MNF) for its grant of sea time on the $\mathrm{R} / \mathrm{V}$ Investigator and associated personnel, scientific equipment, and data management. The first author extends gratitude to the ECMWF support team, Paul Berrisford, and Anton Beljaars for their help. Last, we acknowledge the crucial roles played by Tom Trull (CSIRO), the lead chief scientist, Tegan Sime, the $\mathrm{MNF}$ voyage manager, and the Investigator crew on making this research voyage a success. We thank the editor and two anonymous reviewers whose valuable suggestions significantly improved this paper. The CAPRICORN 2016 data archive is available from NOAA (gov.noaa.nodc:0170257; https://www.nodc.noaa. gov/archivesearch/rest/find/document? $\mathrm{f}=$ searchPage \& searchText $=0170257 \& x=0 \& y=0)$.

\section{REFERENCES}

Balsamo, G., and Coauthors, 2015: ERA-Interim/Land: A global land surface reanalysis data set. Hydrol. Earth Syst. Sci., 19, 389-407, https://doi.org/10.5194/hess-19-389-2015.

Bariteau, L., C. Fairall, B. Blomquist, and S. Pezoa, 2018: CAPRICORN 2016 field campaign: Surface meteorological data and turbulent fluxes collected from the RV Investigator by the National Oceanographic and Atmospheric Administration (NOAA) in the Indian and South Pacific Oceans from 2016-03-14 to 2016-04-15. NOAA/National Centers for Environmental Information, accessed 17 August 2018, https:// doi.org/10.7289/V5Q81BBC. 
Beljaars, A. C. M., 1998: Air-sea interaction in the ECMWF model. Seminar on Atmosphere-Surface Interaction, Reading, United Kingdom, ECMWF, 33-52.

Bourassa, M. A., and Coauthors, 2013: High-latitude ocean and sea ice surface fluxes: Challenges for climate research. Bull. Amer. Meteor. Soc., 94, 403-423, https://doi.org/10.1175/ BAMS-D-11-00244.1.

Bradley, F., and C. Fairall, 2006: A guide to making climate quality meteorological and flux measurements at sea. NOAA Tech. Memo. OAR PSD-31, 44 pp., https://www.oceanbestpractices.net/ bitstream/handle/11329/386/fluxhandbook_NOAA-TECH\% 20PSD-311v3.pdf? sequence $=1 \&$ is Allowed $=y$.

Brunke, M. A., X. Zeng, and S. Anderson, 2002: Uncertainties in sea surface turbulent flux algorithms and data sets. J. Geophys. Res., 107, 3141, https://doi.org/10.1029/2001JC000992.

— C. W. Fairall, X. Zeng, L. Eymard, and J. A. Curry, 2003: Which bulk aerodynamic algorithms are least problematic in computing ocean surface turbulent fluxes? J. Climate, 16, 619-635, https://doi.org/10.1175/1520-0442(2003)016<0619: WBAAAL $>2.0 . \mathrm{CO} ; 2$.

_- Z. Wang, X. Zeng, M. Bosilovich, and C. L. Shie, 2011: An assessment of the uncertainties in ocean surface turbulent fluxes in 11 reanalysis, satellite-derived, and combined global datasets. J. Climate, 24, 5469-5493, https://doi.org/ 10.1175/2011JCLI4223.1.

Chou, S. H., E. Nelkin, J. Ardizzone, R. M. Atlas, and C. L. Shie, 2003: Surface turbulent heat and momentum fluxes over global oceans based on the Goddard satellite retrievals, version 2 (GSSTF2). J. Climate, 16, 3256-3273, https://doi.org/ 10.1175/1520-0442(2003)016<3256:STHAMF $>2.0$. CO;2.

Colbo, K., and R. A. Weller, 2009: Accuracy of the IMET sensor package in the subtropics. J. Atmos. Oceanic Technol., 26, 1867-1890, https://doi.org/10.1175/2009JTECHO667.1.

Curry, J. A., and Coauthors, 2004: SEAFLUX. Bull. Amer. Meteor. Soc., 85, 409-424, https://doi.org/10.1175/BAMS-85-3-409.

Dee, D. P., and Coauthors, 2011: The ERA-Interim reanalysis: Configuration and performance of the data assimilation system. Quart. J. Roy. Meteor. Soc., 137, 553-597, https://doi.org/ 10.1002/qj.828.

Dong, S., S. T. Gille, and J. Sprintall, 2007: An assessment of the Southern Ocean mixed layer heat budget. J. Climate, 20, 4425-4442, https://doi.org/10.1175/JCLI4259.1.

ECMWF, 2015a: IFS documentation-Cy41r operational implementation 12 May 2015. Part IV: Physical processes. ECMWF Rep., 210 pp., https://www.ecmwf.int/sites/default/ files/elibrary/2015/9211-part-iv-physical-processes.pdf.

- 2015b: IFS documentation-Cy41r1 operational implementation 12 May 2015. Part VII : ECMWF wave model. ECMWF Rep., 83 pp., https://www.ecmwf.int/sites/default/ files/elibrary/2017/17739-part-vii-ecmwf-wave-model.pdf.

Edson, J. B., 2008: Review of air-sea transfer processes. ECMWF Workshop on Ocean-Atmosphere Interactions, Reading, United Kingdom, ECMWF, 7-24, https://www.ecmwf.int/ sites/default/files/elibrary/2009/9260-review-air-sea-transferprocesses.pdf.

_ 2015: Improved parameterization of heat, mass and momentum exchange for process studies in numerical models. Workshop on Translating Process Understanding to Improve Climate Models, Princeton, NJ, U.S. CLIVAR, https://usclivar.org/sites/default/ files/meetings/2015/presentations/9-Edson_new.pdf.

, and Coauthors, 2013: On the exchange of momentum over the open ocean. J. Phys. Oceanogr., 43, 1589-1610, https:// doi.org/10.1175/JPO-D-12-0173.1.
Fairall, C. W., E. F. Bradley, J. S. Godfrey, G. A. Wick, J. B. Edson, and G. S. Young, 1996a: Cool-skin and warm-layer effects on sea surface temperature. J. Geophys. Res., 101, 1295-1308, https://doi.org/10.1029/95jc03190.

— _ — D. D. Rogers, J. B. Edson, and G. S. Young, 1996b: Bulk parameterization of air-sea fluxes for Tropical OceanGlobal Atmosphere Coupled-Ocean Atmosphere Response Experiment. J. Geophys. Res., 101, 3747, https://doi.org/10.1029/ 95JC03205.

,,-- J. E. Hare, A. A. Grachev, and J. B. Edson, 2003: Bulk parameterization of air-sea fluxes: Updates and verification for the COARE algorithm. J. Climate, 16, 571-591, https://doi.org/ 10.1175/1520-0442(2003)016<0571:BPOASF $>2.0 . C O ; 2$.

— and their role in climate variability and predictability. OceanObs'09: Sustained Ocean Observations and Information for Society, Venice, Italy, ESA, 299-313, https://doi.org/10.5270/ OceanObs09.cwp.27.

Fasullo, J. T., and K. E. Trenberth, 2008: The annual cycle of the energy budget. Part I: Global mean and land-ocean exchanges. J. Climate, 21, 2297-2312, https://doi.org/10.1175/ 2007JCLI1935.1.

Frenger, I., N. Gruber, R. Knutti, and M. Münnich, 2013: Imprint of Southern Ocean eddies on winds, clouds and rainfall. Nat. Geosci., 6, 608-612, https://doi.org/10.1038/ngeo1863.

Gille, S., M. A. Bourassa, and C. A. Clayson, 2010: Improving observations of high-latitude fluxes between atmosphere, ocean, and ice. Eos, Trans. Amer. Geophys. Union, 91, 307, https://doi.org/10.1029/2010EO350003.

Herman, A., 2015: Trends and variability of the atmosphere-ocean turbulent heat flux in the extratropical Southern Hemisphere. Sci. Rep., 5, 14900, https://doi.org/10.1038/srep14900.

Janssen, P. A. E. M., 2008: Air-sea interaction through waves. Workshop on Ocean-Atmosphere Interactions, Reading, United Kingdom, ECMWF, 47-60, https://www.ecmwf.int/sites/ default/files/elibrary/2009/10218-air-sea-interaction-throughwaves.pdf.

Jiang, C., S. T. Gille, J. Sprintall, K. Yoshimura, and M. Kanamitsu, 2012: Spatial variation in turbulent heat fluxes in Drake Passage. J. Climate, 25, 1470-1488, https://doi.org/10.1175/ 2011JCLI4071.1.

Josey, S. A., E. C. Kent, and P. K. Taylor, 1999: New insights into the ocean heat budget closure problem from analysis of the SOC air-sea flux climatology. J. Climate, 12, 2856-2880, https:// doi.org/10.1175/1520-0442(1999)012<2856:NIITOH $>2.0 . C O ; 2$.

_ L. Yu, S. Gulev, X. Jin, N. Tilinina, B. Barnier, and L. Brodeau, 2014: Unexpected impacts of the tropical Pacific array on reanalysis surface meteorology and heat fluxes. Geophys. Res. Lett., 41, 6213-6220, https://doi.org/10.1002/2014GL061302.

Lindsay, R., M. Wensnahan, A. Schweiger, and J. Zhang, 2014: Evaluation of seven different atmospheric reanalysis products in the Arctic. J. Climate, 27, 2588-2606, https://doi.org/10.1175/ JCLI-D-13-00014.1.

Liu, J., T. Xiao, and L. Chen, 2011: Intercomparisons of air-sea heat fluxes over the Southern Ocean. J. Climate, 24, 1198-1211, https://doi.org/10.1175/2010JCLI3699.1.

Mace, G. G. J., and A. Protat, 2018: Clouds over the Southern Ocean as observed from the $\mathrm{R} / \mathrm{V}$ Investigator during CAPRICORN. Part I: Cloud occurrence and phase partitioning. J. Appl. Meteor. Climatol., 57, 1783-1803, https://doi.org/ 10.1175/JAMC-D-17-0194.1.

Reynolds, R. W., T. M. Smith, C. Liu, D. B. Chelton, K. S. Casey, and M. G. Schlax, 2007: Daily high-resolution-blended analyses for 
sea surface temperature. J. Climate, 20, 5473-5496, https:// doi.org/10.1175/2007JCLI1824.1.

Santorelli, A., 2011: Differences between two estimates of air-sea turbulent heat fluxes. J. Geophys. Res., 116, C09028, https:// doi.org/10.1029/2010JC006927.

Schulz, E. W., M. A. Grosenbaugh, L. Pender, D. J. M. Greenslade, and T. W. Trull, 2011: Mooring design using wave-state estimate from the Southern Ocean. J. Atmos. Oceanic Technol., 28, 1351-1360, https://doi.org/10.1175/JTECH-D-10-05033.1.

— S. A. Josey, and R. Verein, 2012: First air-sea flux mooring measurements in the Southern Ocean. Geophys. Res. Lett., 39, L16606, https://doi.org/10.1029/2012GL052290.

Szczypta, C., J. C. Calvet, C. Albergel, G. Balsamo, S. Boussetta, D. Carrer, S. Lafont, and C. Meurey, 2011: Verification of the new ECMWF ERA-Interim reanalysis over France. Hydrol. Earth Syst. Sci., 15, 647-666, https://doi.org/10.5194/hess-15-647-2011.

Tomita, H., and M. Kubota, 2006: An analysis of the accuracy of Japanese Ocean Flux Data Sets with Use of Remote Sensing Observations (J-OFURO) satellite-derived latent heat flux using moored buoy data. J. Geophys. Res., 111, C07007, https:// doi.org/10.1029/2005JC003013.

— - T. Senjyu, and M. Kubota, 2016: Evaluation of air-sea sensible and latent heat fluxes over the Japan Sea obtained from satellite, atmospheric reanalysis, and objective analysis products. J. Oceanogr., 72, 747-760, https://doi.org/10.1007/ s10872-016-0368-y.

_ T. Hihara, S. Kako, M. Kubota, and K. Kutsuwada, 2019: An introduction to J-OFURO3, a third-generation Japanese ocean flux data set using remote-sensing observations. J. Oceanogr., $\mathbf{7 5}$, 171-194, https://doi.org/10.1007/s10872-018-0493-x.

Trenberth, K. E., and J. T. Fasullo, 2010: Tracking Earth's energy. Science, 328, 316-317, https://doi.org/10.1126/science.1187272.
Villas Bôas, A. B., O. T. Sato, A. Chaigneau, and G. P. Castelão, 2015: The signature of mesoscale eddies on the air-sea turbulent heat fluxes in the South Atlantic Ocean. Geophys. Res. Lett., 42,1856-1862, https://doi.org/10.1002/ 2015 GL063105.

Weller, R. A., F. Bradley, and R. Lukas, 2004: The interface or air-sea flux component of the TOGA coupled ocean-atmosphere response experiment and its impact on subsequent air-sea interaction studies. J. Atmos. Oceanic Technol., 21, 223-257, https:// doi.org/10.1175/1520-0426(2004)021<0223:TIOAFC>2.0.CO;2.

Yu, L., and R. A. Weller, 2007: Objectively analyzed air-sea heat fluxes for the global ice-free oceans (1981-2005). Bull. Amer. Meteor. Soc., 88, 527-539, https://doi.org/10.1175/ BAMS-88-4-527.

- - _ and B. Sun, 2004: Mean and variability of the WHOI daily latent and sensible heat fluxes at in situ flux measurement sites in the Atlantic Ocean. J. Climate, 17, 2096-2118, https://doi.org/10.1175/1520-0442(2004)017<2096: MAVOTW $>2.0 . \mathrm{CO} ; 2$.

_, X. Jin, and R. A. Weller, 2007: Annual, seasonal, and interannual variability of air-sea heat fluxes in the Indian Ocean. J. Climate, 20, 3190-3209, https://doi.org/10.1175/ JCLI4163.1.

- — , and - 2008: Multidecade global flux datasets from the Objectively Analyzed air-sea Fluxes (OAFlux) Project: Latent and sensible heat fluxes, ocean evaporation, and related surface meteorological variables. WHOI Rep. OA-200801, 64 pp., https://doi.org/10.1007/s00382-011-1115-0.

, Z. Zhang, S. Zhong, M. Zhou, Z. Gao, H. Wu, and B. Sun, 2011: An inter-comparison of six latent and sensible heat flux products over the Southern Ocean. Polar Res., 30, 10167, https://doi.org/10.3402/polar.v30i0.10167. 